\title{
Sutorův kancelářský řád ze 60. let 17. století a jeho vliv na brněnské městské písemnosti
}

\author{
Ludmila Sulitková / Ludmila.Sulitkova@seznam.cz \\ Katedra archivnictví a pomocných věd historických, Filozofická fakulta, Univerzita J. E. Purkyně \\ $\checkmark$ Ústí nad Labem
}

\begin{abstract}
JUC Šebastián Sutor, who worked in Brno between the years 1647 and 1666 as an urban syndic, compiled a unique office order pertaining to the principles of the administration and managing a registry. In this study, the author analyses these principles and, in the context of the research, other official municipal sources of that time and indicates that only documents of an economic and accounting character were exempted from direct supervision of the city council in the 17th century and were administered through the city accounting office (Buchhalterei). The author also states that Sutor's office order, which has not thus far been subjected to any kind of research activity, is unique testimony to, at that time, the very progressive practices of the Brno syndic. These practices were followed in Brno long before they were observed in other cities and foreshadowed 'bureaucratization' of the 18th century in the sense of the orderly management of documents.
\end{abstract}

\section{Keywords}

Brno, urban syndic, Šebastián Sutor, unique office order, city registry, city accounting office

\footnotetext{
$\checkmark$ širši verzi byl tento příspěvek již zveřejněn v jubilejním sborníku kolegyně Aleně Richterové (Sulitková, Ludmila: Výjimečná registratura ze 17. století a iniciativní městský syndik. In: Manu propria... Sborník přispěvků k životnímu jubileu PhDr. Aleny Richterové, CSc. Edd. Zuzana Adamaitis a Tereza Paličková, Praha 2012, s.175-188), jelikož však v rámci tohoto monotematického číla nalézá své prríhodné místo, publikuji jej s laskavým pochopením jmenované kolegyně tedy ještě jednou, a to $v$ zestručněné a modifikované podobě. Ze stávající literatury bylo možné využít pouze starší zpracování Christiana d'Elverta a poznámky Jaroslava Dřímala v jeho průvodci po brněnském městském archivu. D'Elvert, Christian: Beiträge zur Geschichte der königl. Städte Mährens, insbesondere der k. Landeshauptstadt Brünn, 1. Bd., Brünn, 1860 (= Schriften der historisch-statistischen Sektion der k. k. mährischer Gesellschaft zur Beförderung des Ackerbaues, der Natur- und Landeskunde, Bd. XIII), s. 463-466; Drímal, Jaroslav: Archiv města Brna. Průvodce po fondech a sbírkách. Praha 1956, s. 7-12, 18, 40-41, 46-48, 127, 148, 149, 184, 186, 189-190.
} 
Správě registratur na úrovni měst jak v předbělohorské, tak ani v pobělohorské době nebyla dosud v naší novodobé historiografii věnována zasloužená pozornost. Z královského města Brna, na něž se v našem příspěvku zaměříme, jsou z předbělohorského období, jakož i z první poloviny 17. století, zachovány z původní městské registratury jen nepatrné zbytky, ${ }^{1}$ naproti tomu pro léta 1647-1741 jsou dochována tzv. Akta purkmistrovská jako výjimečná, organizovaná spisovna své doby. Tvůrcem této registratury byl JUC Šebastián Sutor, ${ }^{3}$ který, jak se nám podařilo prokázat, přešel do brněnské kanceláře $\mathrm{z}$ Jihlavy, ${ }^{4} \mathrm{kde}$ už také pečoval o městskou spisovnu a odkud byl koncem roku 1646 vykázán Švédy. ${ }^{5}$ Uchýlil se do Brna, kde se zřejmě rychle sžil s místním prostředím a zdejší městskou kanceláří, ${ }^{6}$ takže když si ho jihlavská městská správa chtěla v roce 1647 vyreklamovat zpět, odmítl se už vrátit. ${ }^{7}$ Akta purkmistrovská, jejichž smyslem bylo kromě jiného i oddělení živých akt od přijatých písemností listinné povahy, které vytvářely z dnešního pohledu jakýsi sbírkový archiv, jsou uložena v Archivu města Brna a představují jediný v původním pořádku zachovaný registraturní celek městské správy 17. století v našich zemích, ${ }^{8}$ ačkoli ne zcela kompletní, jak ještě bude naznačeno.

Sutor, který pak působil v brněnské kanceláři téměř dvacet let (a na sklonku života dokonce pronikl mezi městskou elitu a stal se též purkmistrem) ${ }^{9}$ shrnul v roce 1666, krátce před svým skonem, který nastal 13. září, ${ }^{10}$ zásady pro práci v kanceláři do unikátního

1 Ty uspořádal až v polovině 19. století městský archivář Polykarp Koller. V jeho umělém pořádacím systému tvoří první část „Registratura před rokem 1647“, v níž jsou obsaženy jen malé zbytky původních akt, soustředovaných původně u třetí a čtvrté řady listin. Dřímal, J.: Archiv města Brna, s. 774.

2 Archiv města Brna (dále AMB), fond Akta purkmistrovská (dále A 1/8).

3 K osobě Šebastinána Sutora viz práce Ch. d'Elverta a J. Dřímala, citované v úvodní poznámce. Doplnění k Sutorově biografii viz Sulitková, L.: Výjimečná registratura, s. 177-178 a pozn. 6-12 tamtéž.

4 Doposud se soudilo, že do Brna Sutor přesídlil přímo z Buchheimu v Bavorsku, ovšem jeden ze zachovaných rukopisů v brněnském městském archivu, totiž Titulář z roku 1647, nám poskytl indicie k domněnce, že do Brna mohl přijít z Jihlavy. Do jihlavské kanceláře nastoupil jako městský písař dne 6 . května roku 1644. Sulitková, L.: Výjimečná registratura, s. 177-178.

5 Podle laskavého sdělení Vl. Svěráka ze Státního okresního archivu v Jihlavě (součást Moravského zemského archivu v Brně) se jeho odchod dá klást bud' k 20. ř́ijnu nebo 20. listopadu roku 1646. Sulitková, L.: Výjimečná registratura, s. 179 a pozn. 15 tamtéž.

6 Práce v brněnské kanceláři se ujal 11. května roku 1647, 14. září roku 1651 byl přijat za měštana. Sulitková, L.: Výjimečná registratura, s. 179. S největší pravděpodobností ale na sklonku léta roku 1666 již nebyl písařem, protože v období jen o málo starším, nebylo v Brně možné, aby byla kumulována funkce městského písaře s funkcí člena městské rady. Viz Jordánková, Hana - Sulitková, Ludmila: Brněnská městská kancelár v předbělohorském obdobi (Prosopografická a diplomatická a studie), Sborník archivních prací 45/2, 1995, zvláště s. 425. Rejstřík, který vedl k nově utvořené registratuře za svého písařského úřadu sahá až k polovině července roku 1666, což by tedy odpovídalo naznačenému časovému předpokladu.

7 Sulitková, L.: Výjimečná registratura, s. 178 a pozn. 12 tamtéž.

8 Zásluhu na rekonstrukci této unikátní spisovny má J. Dřímal, v letech 1929-1939, 1945-1975 ředitel Archivu města Brna. Srov. úvodní poznámku. Do vzniku hospodářského direktoria v roce 1725 se v Aktech purkmistrovských také ukládaly všechny spisy ekonomické povahy, pro něž se potom utvořila samostatná spisovna. Zvlášt byly ukládány rovněž spisy soudní povahy, z nichž se však zachovaly jen malé zbytky. Dřímal, J.: Archiv města Brna, s. 46, 150, 262.

9 S největší pravděpodobností se tak stalo na sklonku léta roku 1666 - srov. pozn. 6 .

10 Ř́d se sice nedochoval v originále, ale je k dispozici v doslovném přepisu pod názvem „Canzlei-ordnung und Regul von die königlicher Stadt Brünn“ v rukopisném díle „Brünnerische Miscellen“ z konce 18. století, 
kancelářského řádu, určeného jeho následovníkům. V posledním roce svého působení v městské kanceláři sestavil také - jako důležitou pomůcku korespondenčního styku dosud zachovaný titulár. ${ }^{11}$ Zmíněný kancelářský řád představuje první z nám známých speciálních kancelářských instrukcí, upravujících nakládání s dokumenty v městském prostředí. Jak autor podotýká v úvodu ke kancelářskému řádu, byla brněnská městská registratura (tento pojem již běžně užívá), rozvrácena $v$ důsledku švédského obléhání města a on tedy byl ve své funkcí městského písaře veden snahou zavést v ní takový pořádek, aby spisy nebyly neúčelně hromaděny, ale dalo se v nich průběžně dobře vyhledávat informace podstatné pro další úřední jednání. ${ }^{12}$

V první řadě se Sutor soustředil na důsledné oddělení přijatých privilegií od aktového materiálu, ${ }^{13}$ který začal být postupně ukládán spolu s listinným materiálem už někdy od konce 15. stoletî́ ${ }^{14}$ a komplikoval tak orientaci v listinné sbírce. ${ }^{15}$ Snažil se tedy vybrat všechny zásadní písemnosti (privilegia, ale též mandáty a listy) zaručující právní postavení města $\mathrm{v}$ ohledu politickém a hospodářském a $\mathrm{z}$ těch vytvořil 41 věcných oddělení. Každé oddělení bylo označeno heslem, které Sutor napsal na dolní okraje dokumentů, a v rámci oddělení byly potom písemnosti uspořádány důsledně chronologicky. Druhou řadu Sutor utvořil z méně závažných písemností, týkajících se převážně městských statků. Zde byla každá jednotlivina charakterizována stručným vystižením své věcné podstaty, zapsaným na rubu tzv. indorsátem a pořadovým číslem, tvořeným arabskou číslicí (šlo tedy opět o vzestupný chronologický pořádek). Méně důležité písemnosti a aktový materiál z období před rokem 1647 Sutor jen uložil do krabic. Jelikož do současnosti jsou z těchto spisů dochovány jen nepatrné zbytky, dá se pouze hypoteticky přepokládat, že snad bylo alespoň při tomto uložení respektováno jejich starší členění na základní agendy, totiž na spisy ve věcech berních, finančních, politických, soudních, zádušních ad. ${ }^{16}$ Tento starý „archiv“ byl i místně oddělen od spisového materiálu a chován ve zvláštní truhle na radnici (jak Sutor uvádí, alespoň v jeho době měla tato „malá truhla 4 oddělení“). ${ }^{17}$

jehož autorem byl Dr. Karel Hanzely, brněnský gymnasiální profesor a syn městského syndika Antonína Šebastiána Hanzelyho. Brünnerische Miscellen K. J. Hanzelyho byly zamýšleny jako první svazek př́spěvků k dějinám Brna v 17. a 18. století, nemohly ale být pro cenzurní zásah vydány, a tak zůstaly v rukopise, který je od roku 1941, kdy byl předán z Moravského zemského archivu, uložen v Archivu města Brna, fond A 1/3 Sbírka rukopisů a úředních knih, inv. č. 7282 (dále jen AMB, rkp. inv. č. 7282); Ǩád je na fol. 20r-v. $\mathrm{Z}$ tohoto rukopisu Sutorův řád vydal D'Elvert, Ch.: Beiträge zur Geschichte, s. 463-466. Dř́mal J.: Archiv města Brna, s. 183 (srov. úvodní poznámku).

11 AMB, fond A 1/3 Sbírka rukopisů a úředních knih, rkp. inv. č. 133 - viz Obr. 1. S titulářem se evidentně nadále pracovalo (některé zápisy jsou přeškrtnuté), takže se na něm kromě Sutora podílelo, zřejmě později, více písařů.

12 AMB, rkp. inv, č. 7282, fol. 15v-16r. D'Elvert, Ch.: Beiträge zur Geschichte, s. 463.

13 Dřímal J.: Archiv města Brna, s. 7-8, 40.

14 Tamtéž, s. 40.

15 I tato však byla v městském archivu pečlivě tř́děna, a to již od konce 70. let 14. století, kdy do jejího pořádání vnesl na dlouhou dobu závazný pořádek tehdejší přední městský písař Jan z Gelnhausenu. Uspořádáním městského archivu (respektive sbírky listin) zaujímá Brno mezi městskými fondy v našich zemích výjimečné místo. Tamtéž, s. 6-7, 39-40.

16 Tamtéž, s. 39, 46, 74.

17 Podle Sutora byly tyto listiny většinou v latinském a také v českém jazyce. AMB, rkp. inv. č. 7282, fol. 18v; 
Aby se ovšem nemusely vyhledávat potřebné listiny z tzv. archivu v originále, měly k nim být vedeny „dvě knihy neboli kopiáře“ “ ${ }^{18}$ které by byly stále po ruce písaři v kanceláři.

Ze živých spisů vzešlých $\mathrm{z}$ úřadování purkmistrů ${ }^{19} \mathrm{v}$ oblasti politické a hospodářské správy města založil, jak naznačeno, novou registraturu, vedenou podle jeho zásad až do roku $1741 .{ }^{20}$ Jako doklad o městem vyhotovených písemnostech měly být zakládány v registratuře všechny koncepty (a vkládány do knihy vázané v „červené kủži“, kterou syndik nazývá Registraturae Directorium). ${ }^{21}$ Kdokoli by byl nějaký koncept vyzdvihl, aby mohl kvalifikovaně navázat na předchozí jednání, měl jej zodpovědně vrátit na původní místo. ${ }^{22}$ Současně si také měli písaři tyto materiály průběžně pročítat, aby měli v podvědomí potřebné souvislosti. ${ }^{23}$ Tím, že se tedy ukládaly písemnosti in extenso, stalo se zbytečným vést specializované kancelářské knihy, do nichž bylo $\mathrm{v}$ jiných kancelářích obvyklé přepisovat jistým úřadem vydané písemnosti (registra). ${ }^{24}$ Písemnosti purkmistry přijaté i vyřizované měly být propojeny a řádně evidovány, totiž označeny vzestupným číslem v rámci úřední doby každého purkmistra a současně přesným datem a stručným obsahem..$^{25}$ Tak k nim mohl být vyhotovován také rejstř́ik - dodnes je zachován ten, který byl veden samotným Sutorem od 15. května roku 1647 do 13. července roku 1666. ${ }^{26}$ Ten samozřejmě odpovídá dělení fasciklů podle úřadujících purkmistrů a je v něm evidováno více než tři tisíce čísel. ${ }^{27}$

Zmíněný rejstřík k Aktům purkmistrovským a některé další údaje, například ze Staré tereziánské ekonomické registratury, naznačují, ${ }^{28}$ že Sutor nejen na práce v kanceláři dohlížel, ale mnohé i sám vykonával. Byl si rovněž dobře vědom důležitosti dalších spisů a nabádal své nástupce $\mathrm{k}$ jejich řádné evidenci. Každý přední městský písař („syndikus oder Stadtschreiber") měl mít přesný přehled o dluzích města (v souvislosti s dluhy krá-

D’Elvert, Ch.: Beiträge zur Geschichte, s. 465; Dřímal J.: Archiv města Brna, s. 7. Dnes jsou tyto písemnosti uloženy v nepatrných zbytcích v tzv. Registratuře před rokem 1647. Tamtéž, s. 74.

18 „Gemeiner Stadt uralte herrliche Privilegia...welche auch in zwei Bücher oder Copiaria eingetragen, und bei der Canzlei verbleiben, deren Wissenschaft einem Syndico vor allen vernöthen “. AMB, rkp. inv. č. 7282, fol. 18v; D'Elvert, Ch.: Beiträge zur Geschichte, s. 465.

19 Jisté náznaky, že se sami purkmistři snažili ve spisech, jimi vyřizovaných, zavést určitý pořádek a evidenci můžeme spatřovat v Brně již od 20. let 17. století. Dřímal J.: Archiv města Brna, s. 6-7, 46.

20 Tamtéž, s. 46. Srov. též pozn. 8 o odděleném vedení spisů soudní povahy.

21 AMB, rkp. inv. č. 7282, fol. 16v; D’Elvert, Ch.: Beiträge zur Geschichte, s. 464.

22 AMB, rkp. inv. č. 7282, fol. 18r. Tento passus napodiv chybí v D’Elvert, Ch.: Beiträge zur Geschichte.

23 AMB, rkp. inv. č. 7282, fol. 16v; Tamtéž, s. 464.

24 Dř́mal, J.: Archiv města Brna, s. 148.

25 AMB, rkp. inv, č. 7282, fol. 17r; D'Elvert, Ch.: Beiträge zur Geschichte, s. 464. Signatury jsou tvořeny rokem, měsícem nadepsaným M (Monat) a pořadovým číslem, nadepsaným písmenem N, který spis obdržel v rozpětí úřadování určitého purkmistra, tedy například 1647 M XI N 120 - viz Obr. 2. AMB, fond A 1/3 Sbírka rukopisů a úředních knih, rkp. inv. č. 220 - viz Obr. 3. Dřímal, J.: Archiv města Brna, s. 47-48.

AMB, Stará ekonomická registratura města Brna, A 1/9, inv. č. 215 - zde kromě jiného Sutorem poznamenané informace o povolení vstupu Židů do města k 17. březnu roku 1659 a 20 . červenci roku 1661 (viz http://bmsj.eu/data/amb/a1-9/AMB-A-1-9(SR)-215.11-20xls (staženo 26. ř́jina 2011). Ruka těchto zápisů odpovídá Sutorovu autografu. 
lovských měst na Moravě obecně) a hlídat požadavky věřitelů. Zatímco dlužní úpisy se ukládají v originále na radnici, v kanceláři mají být k dispozici jejich kopie. Stejně tak musí mít písař města přehled o písemnostech týkajících se sporů měst s vyššími stavy ohledně daňových povinností. Za zásadní Sutor také považoval vedení protokolů o jednání rady, aby totiž mohl být městský notář průběžně informován o jejích různých rozhodnutích, což se bohužel podle Sutorova zjištění dosud v Brně nedělo (uvádí-li, že takovéto protokoly jsou například vedeny ve Znojmě a Olomouci, je to další doklad jeho obecnějších zkušeností). ${ }^{29}$ A tyto protokoly se pak skutečně začaly pravidelně vést od roku 1667 , kdy už ovšem byl v úřadě Sutorův nástupce. ${ }^{30}$

Sutor však neregistroval všechny spisy. Jak naznačuje v závěru svého řádu, u testamentů to nebylo důležité, protože byly přepisovány do speciálních městských knih, nebyly však evidovány ani rodné listy, svatební i jiné smlouvy, výhostné a prosebné listy a jim podobné, takže není divu, že se z nich v Archivu města Brna dochovala jen nepatrná torza. ${ }^{31}$ Podobně zacházel i s běžnými „posélacími“ listy neboli missivami a žádostmi. Takovéto písemnosti Sutor uspořádal chronologicky, svázal do fasciklů podle let, označil je jako „Allerhand Missiven, Sendschreiben, Supplicationes und dergleichen“ a uložil je ke každému roku registrovaných spisů, jelikož takovéto věci bylo dle jeho názoru možné vyřídit ústně, aby registratura nebyla přiliš rozsáhlá. ${ }^{32} \mathrm{~A}$ ještě jedno Sutorovo konstatování patř́i mezi důležité z hlediska hierarchické struktury městem vyřizovaných záležitostí - explicitně totiž uvádí, že všechny obecné městské účty neboli počty a jejich evidence („manualia“) se nevedou přímo v kanceláři, ale v městské účtárně („Buchhalterei“), i o nich však měl být syndik dobře a pravidelně informován. A tato evidence se pak nacházela pochopitelně př́ímo na radnici v místnosti, kde konšelé úřadovali, čili, jak Sutor naznačuje, byla ukládána „in der Ratsstuben im grünen Kasten“. ${ }^{33}$ Přímo tak potvrdil zjištění získaná pro předbělohorskou dobu diplomatickým a paleografickým rozborem samotných městských písemností. ${ }^{34}$

Sutorův kancelářský řád, byt bohužel badatelsky dosud ve všech souvislostech nedoceněný, tak představuje unikátní svědectví o ve své době velmi progresívních aktivitách

29 AMB, rkp. inv, č. 7248, fol. 19v-20r; D’Elvert, Ch.: Beiträge zur Geschichte. s. 465. Jeho zjištění tedy zcela odpovídá výsledkům výzkumu i pro předbělohorskou dobu, kde bylo naznačeno, že zčásti nahrazovaly roli těchto typů úředních knih v Brně rychtářské knihy. Jordánková, H. - Sulitková, L.: Brněnská městská kancelář, s. 298; Tytéž, Kompetence rychtářského úřadu v Brně. In: pocta Janu Janákovi. Brno 2002, s. 138 a pozn. 63 tamtéž.

30 Dřímal, J.: Archiv města Brna, s. 149.

31 AMB, rkp. inv, č. 7282, fol. 20r; D’Elvert, Ch.: Beiträge zur Geschichte, s. 466.

32 Dřímal, J.: Archiv města Brna, s. 47.

33 AMB, rkp. inv, č. 7282, fol. 19v; D’Elvert, Ch.: Beiträge zur Geschichte. s. 465.

34 Existenci „Buchhalterei“ pro Brno jako první z našich měst už od poloviny 80. let 16. stol. byla doložena na jiném místě - Jordánková, H. - Sulitková, L.: Brněnská městská kancelář zvláště s. 460-461. Účtárna fungovala jako samostatné oddělení městské rady pro správu městských financí, komunikačně ovšem úzce provázané s vlastní městskou kanceláří. Udržela se až do správních reforem konce 18. století, tehdy už však se zmenšenými kompetencemi. 
brněnského syndika, ${ }^{35}$ které daleko dříve nežli bylo zatím možné sledovat v ostatních našich městech, předznamenávaly „byrokratizaci“ 18. století ve smyslu řádné správy dokumentů a tedy utváření př́slušných registratur jako důležité podstaty pro utváření městských fondů neboli archivů (kromě dříve převládajících tzv. listinných archivů jako vlastně sbírek městem přijatých privilegií). ${ }^{36}$ Díky obrovskému úsilí bývalého ředitele brněnského městského archivu J. Dřímala byl tento celek, byt nedochovaný zcela v úplnosti, podle původních rejstř́íků a čísel na dorzech spisů už ve 30 . letech 20. století rekonstruován a postupně inventarizován, ${ }^{37}$ takže může být v současné době všestranně využíván badatelskou veřejností.

35 Výše přitom bylo naznačeno, že původně zřejmě měl v úmyslu vnést své iniciativní nápady do uspořádání registratury už o něco dříve v Jihlavě.

36 Panovnice Marie Terezie například už v roce 1746 změnila na úrovni zemských vlád v Rakousích do té doby dobrovolné vedení protokolů o přijatých a vyřízených spisech v povinné. Systém spisové evidence, založené na čísle jednacím a vedení podacího protokolu, byl pak dopracován v rámci správních reforem Josefa II. v 80. letech 18. století.

37 Sulitková, L.: Výjimečná registratura, s. 181. Srov. též pozn. 8. Akta purkmistrovská byla systematicky inventarizována jak J. Dřímalem, tak dále Jaroslavem Vodičkou, L. Sulitkovou a Janem Flodrem. Jordánkvá, Hana - Sulitková, Ludmila: Archiv města Brna v retrospektivě. In: Městské archivy a městští archiváři. Brno 2010, s. 35 a pozn. 45 tamtéž. 


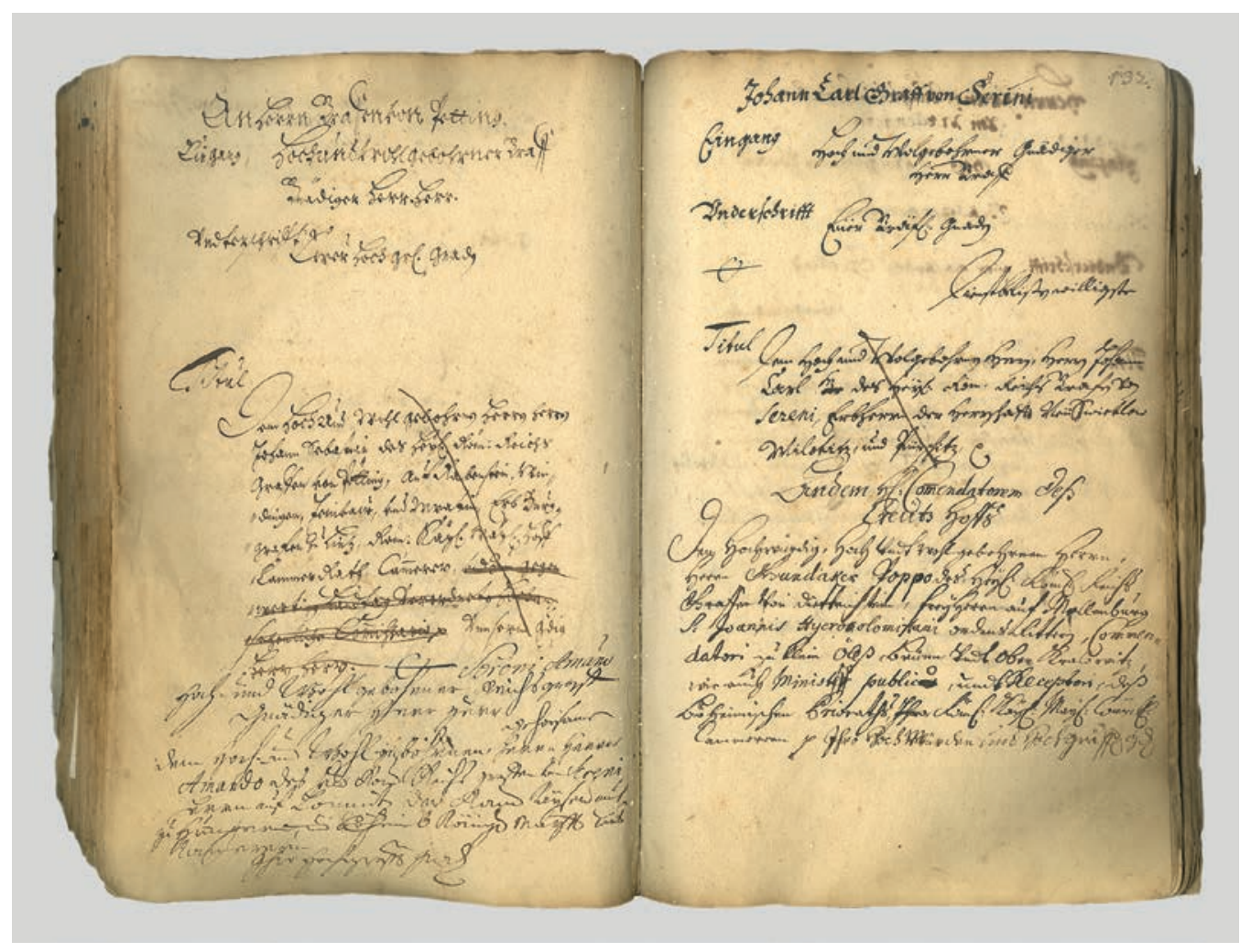

Obr. 1: Titulář sestavený syndikem Šebastiánem Sutorem roku 1666 (AMB, fond A 1/3 Sbírka rukopisů a úředních knih, rkp. inv. č. 133) 


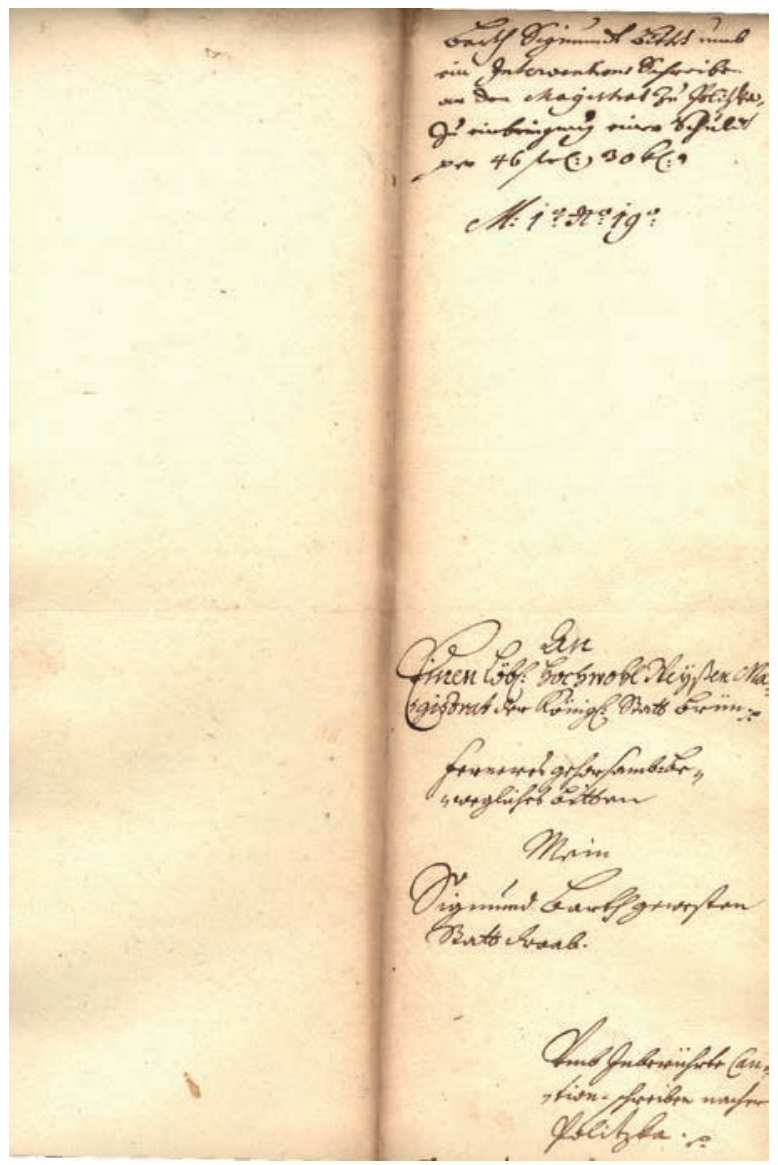

Obr. 2: Ukázka způsobu tvoření signatur v Aktech purkmistrovských k roku 1696 (stále podle Sutorova systému) (AMB, fond A 1/8, Akta purkmistrovská, rok 1696, M1, No 19) 


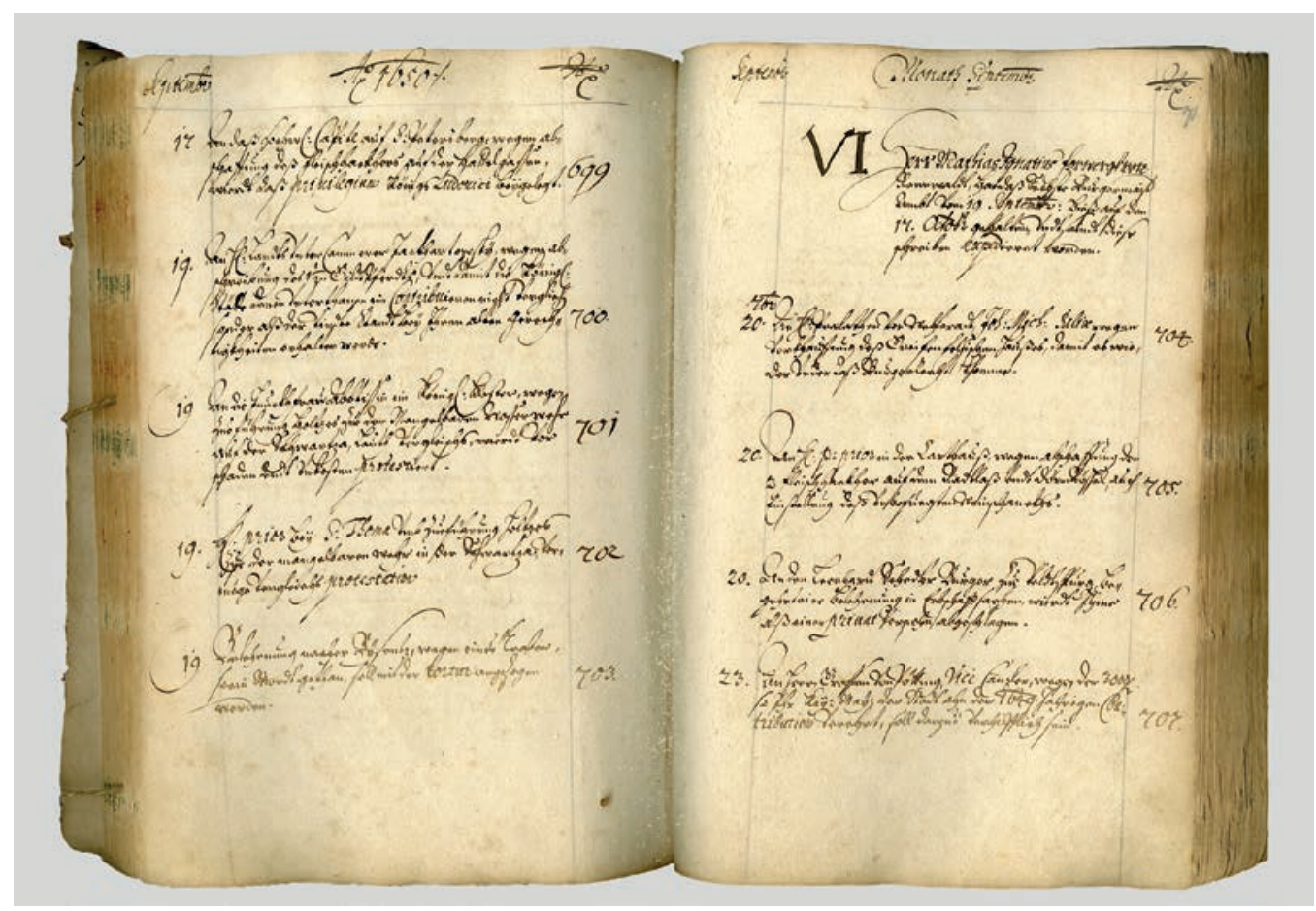

Obr. 3: Syndikem Šebastiánem Sutorem vlastnoručně sepsaný rejstř́k k Aktům purkmistrovským pro léta 1647-1666 (AMB, fond A 1/3 Sbírka rukopisů a úředních knih, rkp. inv. č. 220) 


\section{Sutor's Office Order from the 1660 s and its Influence on Brno Municipal Documents}

The administration of registries in the early modern period at the municipal level has not thus far received the attention it deserves in modern Czech historiography. In his elaboration of the history of Brno as early as the second half of the 19th century, Christian d'Elvert described the unique system of office order for the royal town of Brno dating from the mid-1660s. However, interest in the issue soon subsided. One hundred years later Jaroslav Dřímal returned to the activities of the author of the system, the town syndic Šebastián Sutor, as part of his comprehensive 'Guide to the Archives of the City of Brno'. This work served to deepen knowledge on the subject of Sutor's work in the chancellery of the town of Brno.

Šebastián Sutor joined the municipal chancellery of Brno in 1647, after a short term working in Jihlava, and stayed there for almost 20 years, until 1666. Shortly before his death in September 1666, he compiled the above-mentioned office order for his successors in the office of the city's leading scribe. Sutor emphasized, above all, the fact that the privileges for the city and other essential documents should continue to be kept separately from dossier material. During his time in the Brno chancellery, Sutor arranged the file material according to the term of office of the burgomaster, thus establishing a new registry in Brno (Burgomaster Dossiers), which was kept in the proposed form until 1741. This has mostly been preserved in Brno City Archives and is the only surviving original registry unit of 17 th century municipal administration in the country. The documents received and processed by the burgomaster were consistently inter-referenced, given ascending numbers and abstracts, and a register was also created for them. One that has been preserved to this day was done by Sutor himself in the period 1647 to 1666 . The author analyses in detail Sutor's order, on the basis of which documents were processed and registered. On the basis of a complementary study of other city documents, she concludes that only economic and financial documents were exempted from the direct supervision of the city council and were administered consistently by the city accounting office (Buchhalterei). This has been confirmed by previous research of town documents which revealed that Brno was the only town in the Czech lands using this accounting office already in the period before the Battle of White Mountain. 